\title{
PEMBAGIAN MASKER KEPADA MASYARAKAT DESA BONTOCINI
}

\author{
RAHMIATI \\ 9173770410244 \\ Lavenderhime11\#gmail.com
}

1. Bentuk Kegiatan

- Membagikan masker kepada masyarakat setempat.

2. Lokasi

- Desa Bontocini

3. Hari/Tanggal dan waktu

- Selasa 22 september 2020 pukul 08:30 - 11:35 . Lalu dilanjutkan pada pukul 15:00 - 17:20

4. Peserta yang dilibatkan

- Mahasiswa KKLP Yapti Jeneponto

- Karang Taruna

- Ibu desa Bontocini

- Masyarakat desa Bontocini

5. Alasan diadakannya

Mengingat penyebaran virus covid 19 semakin meningkat, maka pemerintah melakukan gerakan setengah miliar masker. Yakni menyediakan masker sebanyak mungkin lalu membagi-bagikannya kepada masyarakat untuk mencegah penyebaran virus covid 19 semakin meluas terkhusus di jeneponto ini.

6. Tujuan dan Manfaat

Tujuan dan Manfaatnya yaitu mencegah penyebaran virus dengan menggunakan masker setiap bepergian. Sehingga dengan pemakaian masker ini diharapkan dapat menangkal virus-virus yang dapat menyebabkan penyakit.

7. Deskripsi Kegiatan

Kegiatan pembagian masker ini dilakukan di desa Bontocini yang mencakup 4 dusun. Kegiatan pembagian masker ini dilakukan oleh Karang Taruna, Ibu desa Bontocini dan mahasiswa KKLP Yapti 
Jeneponto. Pembagian masker di dua dusun dilakukan pada pagi hari sampai sebelum dzuhur dan dilanjutkan 2 dusun pada sore harinya. Pembagian masker dilakukan dari rumah ke rumah, dan tak lupa pula kami mengedukasi masyarakat untuk memakai masker saat bepergian keluar rumah dan memakaikan masker kepada masyarakat. 